\title{
EDITORIAL
}

\section{Gendered Identities in the Arab World}

The twenty-first century heralded a wave of revolutions that resulted in tumultuous political transformations not only in the Arab world but also across the globe. Radical shifts in the political sphere presented a challenge to researchers and writers to explore the repercussions and/or manifestations of change in social formations and relations. The shifts also raised questions regarding subject formation and the construction and manifestation of gendered identities. It is probably too early to ascertain the extent or depth of the said transformations particularly on subject positions, perceptions and forms of expression amidst a complex and volatile scene. It is also not very realistic to argue that change comes in sudden spouts as we can always trace early signs in earlier works. Hence, this volume engages with some manifestations of change on gendered subjectivities in the twenty-first century. It also sheds light on women's literary and non-literary narratives as forms empowerment.

Transcending binaries is one of the themes that stand out in contributions to this volume. Binarism has always aided the consolidation of gender hierarchies and power relations. In the aftermath of the Arab Spring binary epistemic gendered constructs constitute one of the challenges faced by women. The binaries in question are: secular vs. Islamic, ordinary women vs. elite women, modern vs. traditional. These binaries are entrenched not only in political and media representations and discourses, but also in scholarship. In her article "Writing Feminism and Spirituality against Camus: Ibtihal Salem's Sunduq Saghir fi-l-qalb," Caroline Seymour-Jorn detects an important precursor to the non-ideological feminism of a new generation of women writers. She argues that Salem's short semi-autobiographical novel, A Small Box in the Heart, published in 2004, subverts the essentialist binary opposition between secular and Islamic as she paints a portrait of a woman who is the product of multiple influences and aspirations.

Drawing on interviews with women conducted post 2011, Fatima Sadiqi goes a step further in her analysis of new gendered subjectivities and proposes the concept of the "Center" to characterize a new post-revolution space occupied by the women's movement in North Africa. The Center, she contends, is "a place of diversity," that enables new voices and forms of expression, which transcend the secularist vs. Islamist dichotomy. She identifies some of the features of the women in the Center, namely, a search for a new social contract, an interest in 


\section{Editorial}

establishing transnational alliances, a re-emergence of identity issues and a respect for minority voices, and a focus on combatting sexual harassment. She also detects new strategies in women's activism, such as virtual protests.

In a similar vein, Samar Abdel Salam locates her analysis of the webcomic superhero, Qahera, in Homi Bhabha's third space where identities are not fixed and where negotiations can take place. Written in English, Deena Mohamed, author of the webcomic Qahera, consciously challenges Islamophobic representations of Muslim women and subverts the binary between secular and Islamic women. Qahera, a veiled Muslim woman with super powers emerges as a strong and empowered woman who disrupts dictates of identity promulgated by religious institutions, customs and states. Interestingly enough, the notion of third space is also applied to the genre of the webcomic itself.

Hania Sholkamy engages with another binary, the one that pits elite women against "ordinary" women in scholarship about the Middle East. She challenges the assumption that ethnography enables the understanding of local, native or ordinary people's ideas about gendered identities compared to and in opposition to, narratives by states or local elites. She approaches representations of femininities and masculinities through a complex lens that does not fix categories but rather highlights intersections and connections between multiple narratives about gender.

Another thematic thread comes across in two articles that tackle postrevolution literature. Rana Elbowety examines three literary expressions, a memoir, a novel and a diary, written by three women writers in the aftermath of revolutions: Ahdaf Soueif's Cairo: My City, Our Revolution (2012), Amel Mokhtar's Dukhan al-Qasr (2013) and Samar Yazbek's A Woman in the Crossfire: Diaries of the Syrian Revolution (2012). Drawing on Judith Butler's definition of gender as performative, and Hannah Arendt's link between action and agency, she argues that the three women writers conceive of their writing, as "spaces of enunciation" in which they assert their power, and their agency to document and narrate the revolution. Richard Thomas on the other hand questions the classical post-Third Worldist representation of women in films. He examines films and TV series produced post 2011 and notes that women are represented as political subjects rather than political objects. The role played by women during the protests made the film industry interrogate the stereotypes it had always indulged.

Sama Dawood Salman explores questions of gendered identities through an analysis of testimonies of Arab women refugees collected by Amnesty International in 2016 and published in a report. She demonstrates how women's testimonies are mediated through translation, and in effect, are appropriated and manipulated by various news media to construct different ideological 
viewpoints. The "refugee crisis" is packaged and reworked either to affirm or challenge policy directions in different countries. Refugee women variously appear as victims and/or as powerful voices of survivors of violence and hardship. Finally, one of the important developments in scholarship on the Arab world post 2011 has been the boost in masculinity studies to deconstruct 'imagined masculinities', which enables a subversion of gender roles. Dina Amin revisits a 1990s Egyptian film, Al-Nawm fi al-'Asal (Sweet Slumber), to explore representations of masculinity and femininity. She challenges the sexual politics of the film which consolidate representations of hegemonic masculinity and argues that these representations inevitably imply or necessitate the subordination of women.

The papers in this volume engage with binarisms and stereotypical representations in various manifestations. The writers employ different approaches to read texts- fictional and non-fictional, re-visit forms of artistic expression like films and webcomics, and shed light on activist strategies. Although the 'space of appearance', which has boosted feminist activism and knowledge production post 2011, has shrank conspicuously, much remains to be explored.

Finally, this volume on "Gendered Identities in the Arab World" marks another step forward in the development of Cairo Studies in English (CSE) - the Journal of Research in Literature, Linguistics and Translation Studies, issued since the mid-1950s. It is the first volume in decades which comes with an international flavour, as it includes contributions from authors affiliated to a variety of national, regional and international academic institutions. CSE is reaching out across disciplinary and national borders, and now proudly welcomes among its Advisory Board renowned international scholars, including Susan Bassnett, Uma Chaudhuri, John Carlos Rowe, and Robert Young. The CSE Editorial Board has also succeeded in fulfilling the requirements to be hosted by the Egyptian Knowledge Bank, and can thus achieve considerably wide visibility and accessibility through its page (https://cse.journals.ekb.eg/) a step that would not have been possible without the support $C S E$ received from Prof. Amr Adly, former Vice-President of Cairo University for Postgraduate Studies and Research, who made it possible for CSE to subscribe to Editorial Express (international manuscript management software). We wish also to extend our thanks to all the reviewers of the articles published in this volume, as well as to our colleagues who helped with the copy-editing and proofing, Reem Eldegwi and Amira Fawzi, led by Walid El-Hamamsy, and to the team working on developing the CSE website, Muhamad Kamal and Dalia Youssef, led by Ahmed El-Shamy. 